\title{
75 years of Kwashiorkor in Africa
}

\section{Geert Tom Heikens ${ }^{1}$, Mark Manary ${ }^{1}$ \\ 1 College of Medicine, Blantyre, Malawi}

In fact, a name means very little except to classify a certain conception. Until pathologists and biochemists can give us more precise information about the defects, we may well accept the word kwashiorkor in all its cacophony.

\section{Cicely Williams, 1953.}

Childhood malnutrition has been with us since the early days of humanity. Its epidemiology, determinants and aetiology, nomenclature, pathophysiology, case management and ultimately prognosis has kept many -practitioners, scientists and policymakers- lifelong intrigued and involved. In the following (incomplete) overview we use kwashiorkor as the icon for life threatening childhood malnutrition and discuss its history in Africa and the relevant achievements in its case management today .

\section{Kwashiorkor, first mentioned and in search for an etiological explanation}

In 1933, Cicely Williams was the first in Africa to describe kwashiorkor, the nutritional disease of childhood associated with a maize diet. The distinguishing feature was the presence of oedema, and the rapid demise of these children. Oedema as a result of famines had been known since biblical times (Deuteronomy 8-4), and in Lamentations 5-10 the typical skin changes seen in kwashiorkor "our skin was black like oven because of terrible famine" were reported. Oedematous malnutrition had been described in Europe's medical literature since the eighteenth century and associated with monotonous diets, Mehlnahrschaden or "flour dystrophy", and concurrent infections such as measles. One of the earliest descriptions from the tropics was in Mexico by Hinajosa and later more detailed by Guillon in1913, who described bouffissure d'Annam (swelling disease of Viet Nam), and it was Williams who gave it the African name kwashiorkor after the notion in the Galanguage kwa ni oshi korkor, meaning "pretend not to mind korkor (= the second one)". Williams carefully suggested that "as maize was the only source of the supplementary food, some amino acid or protein deficiency cannot be excluded as cause". However, many after her assumed kwashiorkor was the result of protein deficiency, and unfortunately still many of today's textbooks propagate this supposition. Hugh Trowell (1940 ) was impressed by the flaky paint dermatosis of kwashiorkor, and suggested that it was similar to infantile pellagra. Trowell was the first to find that the serum albumen concentration in children with kwashiorkor was below normal, a finding used to support the hypothesis that a protein deficient diet was at the basis of this syndrome. Waterlow, initially working in the Gambia before moving to Jamaica, was the first to observed fatty liver in oedematous malnutrition, a finding which triggered of his lifelong quest in the protein metabolism in these children. Just after the 2nd World War in Wuppertal, McCance and Widdowson studied undernutrition in German orphans, work which formed later the basis of their experiments in Cambridge in which both investigated the partitioning of protein and energy in growing animals . Boyd Orr, groomed in animal and human nutrition in Cambridge with latter two and one of the first public health nutritionists, was the first Director of the UN Food \& Agriculture Organisation. Hence, it is not surprising that kwashiorkor and undernutrition were major issues in FAOs first engagement with the other newly established UN organisation the World Health Organisation. As a result the First Joint FAO/WHO Expert Committee on Nutrition requested (in 1948) a survey on the "most widespread nutritional disorder kwashiorkor" in tropical Africa, South of the Sahara. The outcome of which was Brock \& Autret's report Kwashiorkor in Africa (1952), published as one of the early WHO Bulletins. Most of their information and to the $\mathrm{WHO} / \mathrm{FAO}$ were hospital-based case-studies, hence the bias for kwashiorkor over stunting and wasting as

nutritional disorders. Kwashiorkor continued to preoccupy nutritionists and practitioners like Trowell, Davies and Dean who wrote a comprehensive treatise Kwashiorkor compiling over 600 articles on kwashiorkor. They alluded already how fashions in medicine, and to what now would be called clinical nutrition, coloured the explanation for the multiplicity of signs and symptoms observed in malnourished children: electrolytes, vitamins, amino acids \& protein, hormones, and later.......micronutrients and free radicals..

\section{Contrasting theories, dogmatic educational materials and unsettled professionals.}

In the following decades, physicians once acquainted with this clinical syndrome and facing larger numbers of sick, malnourished children in modest health care facilities, offered through more systematic studies. Gopalan described the association childhood malnutrition to low energy intakes, and not necessarily a low protein intake observed in hundreds of thousands Indian malnourished children. The paradigm maintaining that protein deficiency was the most important nutrient deficiency in childhood was questioned. Rutishauser described the factors affecting the intake of protein and energy in preschool Ugandan children, and the effect of the traditionally diets low in fat, energy and protein on their serum protein and body weight. Weaning diets consisting of dilute plaintain or maize porridge given at an age when child growth-velocity rates, and thus energy requirements, are high, resulted in energy deficiency. Hence, protein seemed not to be the main cause of kwashiorkor and kwashiorkor not the most prevalent form of malnutrition.

\section{The Protein Fiasco and Energy Gap}

McLaren reconsidered protein requirements, and as critical and socially conscious practitioner, sparked the debate on "the great protein fiasco". He refers to the ubiquitously held belief behind the dietary origin of malnutrition, and one governing many global, national and curative medical policies to enrich diets with "high quality" proteins, to close the protein "gap" and improve the lives of "growing bodies". Waterlow and Payne published in Nature the confirmatory biochemical basis to McLaren's insight. However, the political world was convinced that proteins were good for health and the economy, and the UN-Protein Advisory Group was established. It was McLaren who debunked the myth that kwashiorkor was globally the predominant form of childhood malnutrition, and he rightfully asked more attention be paid to marasmus. He summarised how case-studies on childhood malnutrition, in the three decades following Cicely William's 
first description of kwashiorkor, were used to show that these "poor children in Africa" needed high protein diets. Aforementioned UN-bodies WHO and FAO, concerned with this lack of nutrients and childhood malnutrition, found in "poor" farmers North of the equator -who over decades formed a powerful block of voters- a sensitive target. Hence these farmers received subsidies for increasing the milk output, leading to national surpluses. Skimmed milk was sent as humanitarian assistance to the poor children, from mainly subsistence and hardly surviving farmers, in Africa. The remaining butter mountains in Europe and the USA led to new subsidies, wealthy farmers and highly mechanised farms; all contributing to this highly subsidised inequity in the world. African small holding farmers were unable to produce competitively locally, as well as on the world market; a protracted global injustice only addressed as recent as this month (2009) in the G8 by Obama's new initiatives to stop food aid. If this promise is kept, which would be unique for pledges at such meetings, this initiative would alter the face and outcome of development assistance as well as reduce hunger

\section{Different pathways in the development of oedema?}

The Cambridge group, with its field stations in Uganda and The Gambia, accepted that the diets of children with kwashiorkor did not differ in energy and protein content. Lunn et al suggested that the oedema in the Gambian children was associated with a precipitous drop in plasma albumen associated with increased gut permeability for proteins and amino acids, while in the oedematous Ugandan a more gradual development of oedema was associated with changes in serum cortisol and serum amino acid concentrations not found in the Gambian children. In Jamaica, the clinical evidence that lack of protein neither causes oedema nor that protein supplementation resolves oedema was addressed through successive dietary studies by the Goldens and Jackson . The Jamaican group investigated the metabolic response to physiologic stress in malnourished children and observed that glutathione depletion was associated with the genesis of oedema. Reductive adaptation takes place following changes in the child's body composition, involving changes at cellular, organ and systems level, all resulting from metabolic changes involving trace elements, vitamins, substrate and their intermediary metabolism. Superimposed on the reduced response to these perturbations is the lack of a normal immune modulation as many of these children are chronically infected. Golden and Ramdath demonstrated that oedematous children had low levels of antioxidants (superoxide dismutase enzymes and glutathione peroxidise), vitamin A, E, C, and carotene, and excreted oxidised products of glutathione in their urine. The presence of free iron induces these oxidation and therefore is not given to the child kwashiorkor during the first phase of therapy. Golden postulates that oedema is the result of an excess of free radicals produced in response to stress, such as acute infection or toxin exposure, and hence a metabolic imbalance due to a lack of anti oxidants. As there can be as many as 14 different antioxidants, kwashiorkor might more appropriately be associated with micronutrient deficiencies than with a macro deficiency. The clinical presentation of children with kwashiorkor is not dissimilar from those suffering from severe septicaemia often with compromise to many organ systems . Case management of children suffering from kwashiorkor following the 1999 WHO therapeutic guidelines reduced case fatality rates to as low as 5\% . Ciliberto et al. tested the hypothesis and evaluated the efficacy of antioxidant supplementation in preventing kwashiorkor in a population of Malawian children at high risk of developing kwashiorkor through a prospective, double blind, placebo controlled trial randomized by household in 8 villages in rural southern Malawi: 2372 children in 2156 households aged 1-4 years were enrolled and 2332 completed the trial. Daily supplementation with an antioxidant powder containing riboflavin, vitamin $\mathrm{E}$, selenium, and $\mathrm{N}$-Acetylcysteine in a dose that provided about three times the recommended dietary allowance of each nutrient or placebo for 20 weeks. Antioxidant supplementation did not prevent kwashiorkor, nor were there fewer cases of kwashiorkor among the children receiving antioxidants, suggesting that the antioxidant supplementation was partially effective. However, important as this study is, neither the antioxidant capacity nor oxidative stress was measured. The etiology of kwashiorkor remains an enigma, and is likely to be multifactorial and thus excludes one simple uniform preventive and therapeutic approach.

\section{The synergism between malnutrition and infections}

In the 1960s and 1970x, contributions to the understanding of childhood malnutrition came from central American studies by Mata, and Scrimshaw, Taylor and Gordon . Mata studied the effect of recurrent acute infections, acting through malabsorption, catabolism and anorexia on nutrition and growth in Guatemalan children. The synergism between infection and childhood malnutrition was firmly established and continues to form the basis for new interventions to improve child survival. Since Gracey and Mata described the nutritional and metabolic consequences of intestinal microbial colonisation the concept of contaminated bowel syndrome became an essential element in the case management of malnourished children resulting in their improved growth rates, reduced incidence rates of kwashiorkor and reduced failure rates in community based treatment. While the Cambridge group in Uganda highlighted the low energy density of weaning gruel as a determinant of under five malnutrition, in The Gambia their work focused on the high levels of bacterial contamination of weaning foods in relation to (protracted) infantile diarrhoea and the development of malnutrition. The Jamaican group also investigated bacterial colonisation of feeding utensils and found, like the group in The Gambia, neither a correlation between concurrent diarrhoea and this contamination. However, it described the frequent occurrence of the contaminated bowel syndrome in a more fundamental physiological context and coined the term Human Rumen . They argue "whether an infant suffers gastro enteritis or not, and whether that gastro enteritis ushers a cycle of recurrent diarrhoea depends not only on the faecal contamination of the feed, but also upon the child's ability to resist the establishment of the pathogen in the bowel. When the child has been breastfed and it is healthy with an intact immune system, gastric acidity, intestinal motility and a normal resident flora, the contaminated feed can be ingested with relative impunity. If on the other hand these factors are disturbed by deprivation of colostrum and breast milk, feeding diets low in specific nutrients such as zinc, or if the child develops measles, then the contaminating organisms can establish themselves". 


\section{Anthropometric classifications of malnourished children and their dietary costs of growth.}

In the 1970s the emphasis moved away from kwashiorkor and protein, and among clinical nutrition scientists and child health practitioners it was realised that wasting and marasmus, and its associated catabolic diseases, were more predominant. The case definitions, and anthropometric classification, became more practical and intervention oriented. In 1972 the classification according Gomez (who in the nineteen fifties developed the first risk/mortality) through defining the child's status in terms of its weight-for-age, was replaced by the Wellcome classification. Waterlow, designing this classification was still focussing on the clinically fascinating and epidemiologically less prevalent forms of oedematous malnutrition, and still used the Gomez's anthropometry in terms of weight for age with and without oedema. Waterlow, realising that with increasing age the Gomez classification did not accurately reflect anymore changes in body composition in the older child, and that it neither indicated that these children faltered in linear growth, designed the Waterlow classification . Latter made, by using weight for height (and thus independent from age), a clear distinction between wasting, an expression of altered body composition with loss of adipose tissue (and fluid), and height for age as an expression of stunting, being too short. Stunting has unfortunately rarely been recognised as an remedial nutrient deficiency in these days, partly because it was not recorded, as height measurements were practically rarely done and considered too difficult and often inaccurate. Stunting is, anno 2009, being recognised as the most prevalent form of nutrient deficit and strongly associated with periods of sustained poverty and monotonous protein poor diets. The Lancet Undernutrition Series (ref) highlighted the various deleterious aspects clearly. Wasting is seen as acute forms of malnutrition and expression of catabolism and disease related deficiency, and not for nothing, when first described in 1983 in Uganda, was HIV called Slim disease and was Tuberculosis in Shakespearean English called consumption. The use of the Mid Upper Arm Circumference (MUAC) originates from the same period of the nineteen seventies but only found justification after introduction by the increasingly globally important and scientifically based dietary interventions through humanitarian assistance in the last decade of the 20th century. It is only since this year that WHO \& UNICEF guidelines emphasise the use of MUAC and its simply measured cut-off-points.

It was Micheal Golden who proposed a nutritional rationale behind the anthropometric classification in children. Children facing a deficiency of, so called, type I nutrients show this with clinical specific signs while those lacking type II nutrients falter in their linear growth. This would explain how children with a normal stature or even tall and or obese can be suffering from a thiamine, vitamin A or -E deficiency; while children with inadequate dietary intakes of i.e. zinc, protein, potassium, sulphur and phosphorus have become wasted and stunted as their lean tissue accretion was halted.

Consistent with his new developments in designing more appropriate anthropometric classifications the group lead by John Waterlow started looking into the biochemical and nutritional aspects of body composition and (catch-up) growth. Garrow described the causal relationship between potassium, and other electrolytes, with lean tissue loss and accretion. At the same time Ashworth , extending the work in Makerere, pioneered the notion of energy of (catchup) growth. Both aspects were translated in the evidence based therapeutic guidelines for the case management of malnourished children an update from such first guidelines developed in Kampala, Uganda.

\section{Whether weanling or suckling dilemma: it is pragmatically addressed by RUTF}

Waterlow calculated on the basis of the normal growth rates of infants that the energy content of breast milk of an average breastfeeding mother would become inadequate for that infant just over 4 months. Santi Gosh, an Indian Child Health specialist, always recommended to continue breastfeeding and wean infants as late as 6-8 months, accepting their growth faltering over the risk of morbidity and mortality from recurrent infections, from which exclusive breastfeeding protects. To address this emerging dietary energy and micronutrient inadequacy and at the same time have a well balanced and hygienically safe dietary supplement for malnourished children in need of humanitarian assistance, Briend developed RUTF. Field testing continued and other new formulae and spreads were developed in Malawi by the Malawian Project Peanut Butter. Presently latter annually produces hundreds of tons of this ready-to-use therapeutic food (RUTF) for the domestic market. WHO and UNICEF have both embraced the development CTC and through their potential high coverage, facilitated by using standardised protocols, simple detection techniques through MUAC, local production and wide availability of RUTF and these programmes have, mainly through increased coverage, greatly improved outcome of uncomplicated SAM . Interestingly the experiences with CTC have improved the efficiency and effectiveness of institutional care of malnourished children , and therefore enables us to address malnutrition where it matters .

\section{Where from here?}

In 2009, we have an effective treatment strategy to correct wasting and to address many aspects of the clinical syndrome kwashiorkor. The arrival of HIV has dramatically altered the epidemiology, presentation, pathophysiology and outcome of malnutrition and puts many of us back to study these children in ward and laboratories, studies which in non-HIV infected malnourished children has offered us the wealth of science and therapeutic responses referred to above. Part II will address the challenges we face treating malnourished children in HIV prevalent communities, and Part III the studies which are needed to define, in another attempt, the precise aetiology of kwashiorkor in order to develop more effective preventive strategies.

This is part I of a Trilogy on Kwashiorkor; addressing why paediatricians remain interested in this important and yet still not completely unraveled syndrome. Part 1 address the historical aspects of kwashiorkor, in part II the challenges malnourished children face in environments with a high prevalence of HIV infection are being discussed, and in part III we hypothesize how we can continue to unravel this syndrome.

\section{References}

1. Williams C. Kwashiorkor. JAMA, 1953: 153: 1280. 
2 Williams C. A nutritional disease of children associated with a maize diet. Arch Dis Childh 1933; 8: 423-28.

3. Williams C. Kwashiorkor; a nutritional disease of children associated with a maize diet. Lancet ii 1935; 1151-2.

4. Rosen von Rosenstein. The Diseases of Children and their Remedies. London: Caldwell, 1776. Reprinted first English edition by the Nutrition Foundation. London: Johnson Reprint Compazny, 1977.

5. Kerpel Fronius E. The pathophysiology of infantile malnutrition: protein energy malnutrition and failure to thrive. Budapest: Akadémiai Kiadó, 1983.

6. Czerny A \& Keller A. Des Kindesernährung, Ernährungsstorungen und Ernährungstherapie. Wien: F Deuticke, 1906.

7. Smith E. On the Wasting Diseases of Infants and Children.

London: John Walton, 1868.

8. Waterlow JC. Protein Energy Malnutrition. London: Edward Arnold, 1992.

9. $\quad$ Trowell HC. Infantile pellagra. Trans R Soc Trop Med \& Hyg 1940; 33: (4) 398-404.

10. Waterlow JC. Fatty liver disease in infants in the British

West Indies. Medical Research Council special report series no. 263.

London: HM's Stationary Office, 1948.

11. McCance RA. The history, significance and aetiology of hunger oedema. pp 21-82. In: Studies of undernutrition, Wuppertal 1946-9. Members of the department of Experimental Medicine, Cambridge, and associated workers. Medical Research Council special report series no. 275. London: HM's Stationary Office, 1951.

12. McCance RA \& Widdowson EM. Nutrition and growth.

Proc R Soc London B 1962; 156: 326-37.

13. McCance RA. Food, growth, and time. Lancet i, 1962; 621-26.

14. McCance RA \& Widdowson EM. The determinants of growth and form. Proc R Soc Lond B 1974; 185: 1-17.

15. Orr JB. Food, Health and Income. London: Macmillan,

1936.

16. Brock JF \& Autret M. Kwashiorkor in Africa. Bull WHO

1952; 5: 1-71

17. Trowell HC, Davies JNP \& Dean RFA. Kwashiorkor. London: Edward Arnold, first published 1954. reprinted by the Nurition Foundation. New York: Academic Press, 1982.

18. Gopalan C. Kwashiorkor and marasmus: evolution and distinguishing features. pp 49-58. In: Calorie deficiencies and protein deficiency. McCance RA \& Widdowson EM eds. London: Churchill, 1968.

19. Rutishauser IHE \& Whitehead RG. Energy intake and expenditure in 1-3-year-old Ugandan children living in a rural environment. Br J Nutr 1972; 28: 145-52

20. Rutishauser IHE. Factors affecting the intake of energy and protein by Ugandan preschool children. Ecol Food \& Nutr 1974; 3: 213-22.

21. McLaren DS. The Great Protein Fiasco. Lancet ii 1974;

93-96.

22. Waterlow JC \& Payne PR. The Protein Gap. Nature 1976; 258: 113-117.

23. Heikens GT. Rethinking the role of the World Bank in the battle against hunger. Lancet 2009: 374: 281-2.

24. Lunn PG, Whitehead RG, Hay RW \& Baker BA. Progressive changes in serum cortisol, insulin and growth hormone concentrations and their relationship to the distorted amino acid pattern during the development of kwashiorkor. Br J Nutr 1973; 41: 399-402.

25. Lunn PG, Whitehead RG \& Coward WA. Two pathways to kwashiorkor? Trans Roy Soc Trop Med \& Hyg 1979; 73: 438-443.

26. Golden MHN, Golden BE \& Jackson AA. Albumen and nutritional oedema. Lancet i : 1980: 114-16.

27. Golden MHN. Protein deficiency, energy deficiency and the oedema of malnutrition. Lancet i 1982; 1261-65.

28. Golden MHN. The consequences of protein deficiency in man and its relationship to the features of kwashiorkor. pp 169-89. In: Nutritional adaptation in man. Blaxter K \& Waterlow JC eds. London: John Libbey, 1985.

29. Jackson AA. Severe undernutrition in Jamaica. Kwashiorkor and marasmus: the disease of the weanling. Acta Paed Scand (suppl) 1986: 323: 43-51.

30. Golden MHN, The effects of malnutrition in the metabolism of children. Trans R Soc Trop Med Hyg. 1988: 82: 3-6.

31. Golden MHN \& Ramdath D. Free radicals in the pathogenesis of kwashiorkor. pp. 597-8. In: Proceedings of the XI $\neg$ II Internatio-nal Congress of Nutrition, 1985. Taylor TG \& Jenkins NK eds. London: John Libbey, 1986.

32. Golden MHN. Oedematous malnutrition. British Medical Bulletin 1998: 54 (2): 433-444.

33. Brewster DR, Manary MJ, Menzies IS, O’Loughlin EV \& Henry RL. Intestinal permeability in kwashiorkor. Arch Dis Childh 1997, 76: 236-241.

34. World Health Organisation. Management of severe malnutrition: a manual for physicians and other senior health workers. Geneva: WHO, 1999.

35. Heikens GT. Rehabilitation of sick malnourished children: environment, requirements, prognosis and feasibility. $\mathrm{PhD}$ Thesis, University of Amsterdam. Int. Child Health Studies 1. Amsterdam, Academic Press-Rozenberg Publishers, 2003.

36. Ciliberto H, Ciliberto M, Briend A, Ashorn P, Bier D \& Manary M. Antioxidant supplementation for the prevention of kwashiorkor in Malawian children: randomised, double blind, placebo controlled trial. BMJ. DOI 10.1136/bmj.38427.404259.8F accessed 27072009 .

37. Mata LJ. The children of Santa Maria Cauqué; a prospective field study of health and growth. Cambridge: MIT Press, 1978.

38. Scrimshaw NS, Taylor CE \& Gordon JE. Interactions of nutrition and infection. Am J Med Sci 1959; 237: 367-403.

39. Mata U, Albutazzi C, Pellecier 0 \& Anellano E. Influence of recurrent infections on nutrition and growth of children in Guatemala. Am J Clin Nutr 1972: 24: 126775.

40. Scrimshaw NS, Taylor CE \& Gordon JE. Interactions of nutrition and infection. WHO Monograph series 57. Geneva: World He-alth Organisation, 1968.

41. Black RE, Morris SS, Bryce J. Where and why are 10 million children dying every year? Child Survival Series I. Lancet 2003; 361: 2226-2234.

42. Gracey M, Suharnjo, Sunoto, Stone DE. Microbial contamination of the gut: another feature of malnutrition. Am J Clin Nutr 1973; $26: 1170$.

43. Gracey M. The contaminated small bowel syndrome: pathogenesis, diagnosis and treatment. Am J Clin Nutr 1979; 32: 234-43.

44. Heikens GT, Schofield WN, Christie CDC et al. The Kingston Project III. Morbidity in malnourished children given metronidazole and a high energy supplement during rehabilitation in the community. Eur J Clin Nutr 1993; 47: 174-191.

45. Heikens GT. Rehabilitation of sick malnourished children: environment, requirements, prognosis and feasibility. $\mathrm{PhD}$ Thesis, University of Amsterdam. Int. Child Health Studies 1. Amsterdam, Academic Press-Rozenberg Publishers, 2003.

46. Rowland MGM, Cole TJ \& Whitehead RG. A quantitative study into the role of infection in determining nutritional status in Gambian village children. Br J Nutr 1977; 37: 441-450.

47. Rowland MGM, Barrell RAE \& Whitehead RG. The weanling dilemma: Bacterial contamination in traditional Gambian weaning foods. Lancet i 1978; 136-38.

48. Hibbert JM \& Golden MHG. What is the weanling's dilemma? Dietary feacal bacterial ingestion of normal children in Jamaica. J Trop Ped 1981; 27: 255-258.

49. Jackson AA \& Golden MHN. The human rumen. Lancet ii, $1978 ; 764-767$.

50. Gómez F, Ramos-Galvan R, Frenk S, Cravioto JM, Chávez $\mathrm{R} \&$ Vásquez J. Mortality in second and third degree malnutrition. J Trop Pediatr 1956; 2: 77-83.

51. Waterlow JC. Classification and definition of protein-calorie malnutrition. BMJ 1972; 3: 566-569.

52. Waterlow JC \& Rutishauser IHE. Malnutrition in man. pp 13-26. In: Early malnutrition \& mental development. Cravioto J, Hambraeus L \& Vahlquist B eds. The Swedish Nutrition Found. Stockholm: Almquist \& Wiksell, 1974. 
53. World Health Organization and the United Nations Children's Fund. WHO child growth standards and the identification of severe acute malnutrition in infants and children: A Joint Statement. Geneva: WHO \& UNICEF, 2009.

54. Golden MHN. The role of individual nutrient deficiencies in growth retardation of children as exemplified by zinc and protein. pp 143-65. In: Linear growth retardation in less developed countries. Waterlow JC ed. Nestlé Nutrition Workshop Ser. Vol. 14. New York: Raven Press, 1988.

55. Waterlow JC. The rate of recovery of malnourished infants in relation to the protein and calorie levels of the diet. J Trop Pediatr 1961; 7: 16-22.

56. Garrow JS, Fletcher K \& Halliday D. Body composition in severe infantile malnutrition. J Clin Investigation 1965, 45: 417-25.

57. Garrow JS, Smith R \& Ward EE. Electrolyte metabolism in severe infantile malnutrition. Oxford: Pergamom Press, 1968.

58. Garrow JS, Picou D \& Waterlow JC. The treatment and prognosis of infantile malnutrition in Jamaican children W I Med J 1962; 11: 217-27.

59. Ashworth A, Bell R, James WPT \& Waterlow JC. Calorie requirements of children recovering from protein-calorie malnutrition. Lancet ii, 1968; 600-603.

60. Ashworth A. Metabolic rates during recovery from protein calorie malnutri $\neg$ tion: the need for a new concept of specific dynamic action. Nature 1969; 223: 407-9.

61. Ashworth A. Growth-rates in children recovering from protein-energy malnutrition. B J Nutr 1969; 23: 835-45.

62. Rutishauser IHE \& McCance RA. Calorie requirements for growth after severe undernutrition. Arch Dis Childh 1968: 43: 252-56. 63. Picou D, Alleyne GAO, Brooke O, Kerr DS, Miller C, Jackson AA, Hill A, Bogues J \& Patrick J. Malnutrition and gastroenteritis in children; a manual for hospital treatment and management. Kingston: CFNI/PAHO, 1975.

64. National Food and Nutrition Council of Uganda and MRC Child Nutrition Unit. The therapy of the severely malnourished child; a practical manual. Kampala: NFN Council, 1973.

65. Waterlow JC, Ashworth A \& Griffiths M. Faltering infant growth in less developed countries. Lancet ii 1980; 1176-78.

66. Golden MHN \& Briend A. Conference: Treatment of malnutrition in refugee camps. Lancet 1993: 342: 360.

67. Briend A, Prudhon C, Weise Prinzo Z. et al.. Putting the management of severely malnutrition back on the international health agenda. In: SCN Nutrition Policy paper no.21: WHO, UNICEF, and SCN informal consultation on community-based management of severe malnutrition in Children. Food \& Nutrition Bull. 2006: 27(3): S3-5.

68. Ciliberto MA, Sandige H, Ndekha MJ, et al. Comparison of home based therapy with ready-to-use therapeutic food with standard therapy in the treatment of malnourished Malawian children: a controlled, clinical effectiveness trial. Am J Clin Nutr 2005: 81: 864-70. 69. Sandige H, Ndekha MJ, Briend A, et al. Home-based treatment of malnourished Malawian children with locally produced or imported ready-to-use-food. J Ped Gastro Nutr. 2004; 39: 141-46. 70. Manary MJ, Ndekha MJ, Ashorn P. et al. Home based therapy for severe malnutrition with ready-to-use food. Arch Dis Child, 2004; 89 (6): 557-61.

71. Lapidus N, Luquero FL, Gaboulaud V, Shepherd S \& Grais RF. Prognostic Accuracy of WHO Growth Standards to Predict Mortality in a Large-Scale Nutritional Program in Niger. PLoS 20096 (3): e1000039

72. Kerac M, Bunn J, Seal A, et al. Probiotics and prebiotics for severe acute malnutrition (PRONUT study): a double-blind efficacy randomised controlled trial in Malawi. Lancet 2009; 374: 136-44.

73. World Health Organization and the United Nations Children's Fund. WHO child growth standards and the identification of severe acute malnutrition in infants and children: A Joint Statement. Geneva: WHO \& UNICEF, 2009.

74. Bhutta ZA. Addressing severe acute malnutrition where it matters. Lancet 2009: 374: 94-6. 